\title{
Přemluv bábu, pobav sebe: postmoderní estetika v občanském politickém diskurzu
}

\author{
Kateřina Kirkosová \\ Fakulta sociálních studií \\ Masarykova univerzita \\ Joštova 10, 60200 Brno \\ k.kirkosova@mail.muni.cz
}

V tomto článku analyzuji virální video Přemluv bábu, které mělo ambice zasáhnout do voleb do Poslanecké sněmovny Parlamentu České republiky v roce 2010. Ke klipu přistupuji z pozice kritické diskurzivní analýzy (CDA), pracuji především s předpoklady, koncepty a analytickými nástroji Normana Fairclougha, který pomáhal CDA rozvíjet a $\mathrm{v}$ akademickém poli prosadit. Tvrdím, že klip Přemluv bábu těží z pružnosti, respektive uhýbavosti postmoderního diskurzu, což mohlo smysl jeho výpovědi i její naléhavost spíše oslabit a znečitelnit než podepř́it. Demonstruji na příkladech a snažím se identifikovaným ambivalencím porozumět s ohledem na kontext intertextový, interdiskurzivní, situační a sociopolitický.

Klíčová slova: kritická diskurzivní analýza, politický diskurz, postmodernismus, Přemluv bábu

\section{Úvod}

Rok 2010 byl prvním rokem, kdy nezisková organizace Člověk v tísni uspořádala Studentské parlamentní volby. Fungovaly jako „součást projektu Kdo jiný?, který je realizován v rámci programu Jeden svět na školách a který dlouhodobě podporuje větší účast mladých lidí na občanské společnosti“. ${ }^{1}$ Voleb se zúčastnilo dvacet tisíc středoškoláků star-

1 Člověk v tísni (2010). 
ších patnácti let. Při sloučení dat z gymnázií, stř̌edních odborných škol a středních odborných učilišț ve studentských volbách zvítězila TOP 09 se ziskem 26,59 \% hlasů, následovaly ODS, Věci veřejné, Česká pirátská strana, Dělnická strana sociální spravedlnosti, Strana zelených, ČSSD, SPOZ, KSČM a KDU-ČSL. ${ }^{2}$ Výsledky studentských voleb byly po jistých peripetiích zveřejněny 14 . května, skutečné volby se konaly 28 . a 29. května 2010.

TOP o9 vznikla 28. listopadu 2009 a svou zkratku si poskládala z iniciál slov - hodnot - tradice, odpovědnost a prosperita. Odkazy na „křestansko-židovskou tradici“ Evropy sympatie u studentů zřejmě nevzbudila. Víc rezonovat mohl apel na odpovědnost a prosperitu. ${ }^{3}$ Tyto hodnoty implicitně akcentují horizont přítomnosti, respektive budoucnosti, a mohou být svůdné i v kontrastu s toposem nezodpovědného a nerozumného mládí. Byly navíc zpř́tomňovány v čase globální ekonomické krize roku 2008, která se Evropské unii ani Česku nevyhnula. Toto téma na prŕkladu hospodářské krize $\mathrm{v}$ Řecku $\mathrm{v}$ předvolební kampani do Poslanecké sněmovny Parlamentu ČR v roce 2010 vytěžovala především ODS, která z něj udělala odstrašující př́iklad aplikace levicové politiky. ${ }^{4}$ Zužitkovala jej však i TOP 09. Ta ho přerámovala a transformovala do varování před ČSSD, ale i ODS. Miroslav Kalousek, spoluzakladatel TOP 09, např́ílad v souvislosti s předvolebními plány strany na změny ve zdravotnictví prohlašoval: „Mne nijak netěší, že program TOP o9 je jediný, který skutečně vyvádí Českou republiku z dluhové pasti.“" Protože důkladných analýz či komplexněji shromážděných informací v tehdejším politicko-mediálním prostoru bylo pomálu, ${ }^{6}$ lze pochopit, jak se na takovém podkladu mohla de facto neoliberální politika ${ }^{7}$ TOP 09 mladým voličům jevit jako odpovědná a rozumná.

Studentským volbám i horké části předvolební kampaně se strašákem řecké dluhové krize předcházel svébytný klip Přemluv bábu ${ }^{8}$, v němž

2 Srovnej Strnadová (2010).

3 Srovnej Herzmann cit. in Strnadová (2010).

4 Srovnej Kirkosová, Urbániková \& Volek (2012).

5 Perknerová (2010).

6 Srovnej Keller (2017), Švihlíková \& Tsivos (2017).

7 Srovnej Fairclough (2001).

8 Issová, Mádl \& Zelenka (2010). Odkaz na video a přepis celého textu je k dispozici v editorialu 
dva mladí a populární herci - Martha Issová a Jiří Mádl - vyzývají mladé, aby volili „nějakou novou pravicovou stranu“ a aby přemluvili báby a dědy, své starší př́buzné, aby nevolili levici. Zdálo by se, že minimálně první část jejich apelu dobře koresponduje s preferencemi mladých voličù, a to i kdybychom mezi ,nové pravicové strany' krom TOP o9 zařadili i Českou pirátskou stranu a Věci veřejné, což je kategorizace poněkud sporná. Klip však vyvolal víc kontroverzí než sympatií a zřejmě v tom mnoho nezměnilo ani ex post vysvětlování Issové a Mádla, že sami nejsou pro pravici ani levici ${ }^{9}$ a šlo jim víc o prolomení letargie, lenosti samostatně myslet, za jejíhož hlavního viníka považují čtyřicetiletou vládu komunismu. Tedy že šlo o kritiku neochoty občansky se angažovat a aktivněji participovat na politickém životě země. ${ }^{10}$

Cílem této studie není zjistit, kdo měl v uvedeném sporu ,pravdu' a kdo byl prokazatelně nechápavý. Zajímá mne primárně vnitřní stavba textu klipu, která interpretační disharmonii vyvolala a zapojila jej tak do procesů každodenního vyjednávání společensky uznané pravdy, hegemonie. Předznamenávám zároveň, že studie není standardní empirickou statí, ale má rovněž pedagogickou funkci: ilustrovat postup a analytické nástroje kritické diskurzivní analýzy a krátce tento v současnosti dominantní př́stup ke kvalitativní textové analýze v sociálních vědách představit. Úvodem principy CDA vysvětlím a přiblížím přednosti a limity přístupu. Výzkumný postup demonstruji na trojdimenzionálním modelu CDA Normana Fairclougha a klip Přemluv bábu pomocí jím doporučovaných analytických nástrojů rozeberu. V rozboru se soustředím na strukturu a dílčí prvky videa a rekonstruuji kontext, který předchozí interpretačně ukotvuje.

\section{Kritická diskurzivní analýza: geneze, klíčové koncepty, řešená témata}

Kritická diskurzivní analýza je specifický př́stup k analýze textů, který těmto textům a diskurzům skrze ně cirkulujícím rozumí jako svébytné formě sociálního jednání, které přispívá k reprodukci nebo transfor-

tohoto čísla časopisu na s. 7-9.

9 Hejdová (2016), Vokál (2016).

10 Hřídel (2010), Idnes.cz (2010). 
maci existujících mocenských struktur ve společnosti. ${ }^{11}$ Jako projekt, sdružující výzkumníky studující hru mezi texty, diskurzy, mocí a sociální realitou, se CDA zformovala koncem 80 . let. ${ }^{12}$ Výzkumná pozornost přisuzovaná sledování moci, ideologie a manipulace je v CDA vyjádřena rovněž přívlastkem „kritická“. Ten nemá hodnotící funkci (ve smyslu lepší - horší ve vztahu k diskurzivní analýze). Odkazuje ke kritické teorii, kritickému paradigmatu sociologie. ${ }^{13}$ Jako významné inspirace, byt’ by i jinak interpretované a jinak intenzivní, jsou zmiňovány poststrukturalismus a marxismus, z hlediska disciplín kritická lingvistika, (sociální) sémiotika, kognitivní lingvistika a psychologie a sociologie. Tyto podněty se promítají do společných principů CDA, které individuální imaginaci výzkumníků neeliminují, spíše ji ukotvují a zacilují.

Kritickou diskurzivní analýzu tak lze považovat za „kompletní balíček“14, „ک̌kolu nebo paradigma“"15. Zahrnuje ontologické a epistemologické představy o sociální realitě, teoretické koncepty, metodologické preference $\mathrm{z}$ hlediska volby výzkumných témat a akceptovaných prostředků validace rozborů a analytické nástroje, jež umožňují diskurz v napětí znehybnit a shromáždit tak evidenci pro sledování jeho vnitřních mechanismů. Tato syntéza opět nemá působit direktivně. Apel na interdisciplinaritu, eklektičnost a přizpůsobení designu výzkumu zkoumanému problému je velmi silný. Noví adepti CDA jsou občas i explicitně odrazováni od toho, aby postupy nekriticky přejímali jako kanonické, do nichž by bylo znesvěcující zasahovat. ${ }^{16}$

Dílčí součásti „balíčku“ CDA rozvedu podrobněji. Akcentovanými ontologickými a epistemologickými předpoklady koresponduje CDA s konstruktivistickým paradigmatem sociálních věd. ${ }^{17}$ Přihlašuje se k tezi o konstruovanosti sociální reality ve smyslu neustálého přisuzování významu jejím aktérům, institucím, dějům v ní probíhajícím atp. ${ }^{18} \mathrm{CDA}$

\footnotetext{
11 Wodak \& Meyer (2009), Fairclough (1993, 1995b, 2001), van Dijk (2001).

12 Wodak \& Meyer (2009, s. 3-4).

13 Srovnej Held (1990).

14 Jorgensen \& Phillips (2002, s. 3), srovnej Gee (2005, s. 32-33), Gee (2010).

15 Wodak \& Meyer (2009, s. 3).

16 Srovnej van Dijk (2001).

17 Ritchie \& Lewis (2003), Creswell (2007).

18 Srovnej Berger \& Luckmann (1999).
} 
navrhuje uvažovat o sociální realitě jako o dočasném a kontextově specifickém výsledku interpretačních střetů mezi jinak situovanými a jinak predisponovanými sociálními aktéry. ${ }^{19}$ Význam tedy není považován za inherentní součást symbolických forem (diskurzů) ${ }^{20}$ ani za objektivní, nezávislý na jejich sociálním použití. Existence deskriptivní (nocionální, denotativní) roviny významu tím není popřena, ovšem je nedostačující pro adekvátní interpretaci diskurzu. Krom deskriptivní roviny významu je tak potřeba zohledňovat sociální a kulturní (konotativní) příznaky slov, jejich kontext (Wodak rozlišuje kontext lingvistický, intertextový a interdiskurzivní, situační a socio-historický a politický) ${ }^{21}$. V opačném případě, při interním čtení textu ${ }^{22}$ se zvyšuje riziko interpretace nedostatečné (pouze popisné, k dynamice a vnitřním procesům diskurzu se nepřibližující) nebo přehnané (fabulačně podmanivé, leč s textem a kontextem jeho běžného užití jen minimálně související) ${ }^{23}$.

Text je v CDA pojímán široce, označení platí pro mluvené i psané záznamy řeči, ${ }^{24}$ může zahrnovat i jiné sémiotické systémy nežje jazyk (třeba obrazová, neverbální vyjádření atp.) ${ }^{25}$. Texty jsou považovány za dočasnou stabilizaci diskurzů; texty diskurzy uzamykají v konkretizovaných sémiotických strukturách, aniž by je tím obsáhly kompletně. Diskurz je způsob promluvy, která v sobě implicitně obsahuje naturalizované samozřejmé, nezpochybňované - předpoklady o sociální realitě, jejích institucích či aktérech. ${ }^{26}$ Je sociální praxí, jednáním, jež má stejně jako to nediskurzivní důsledky v žité realitě. Dalším z klíčových pojmů CDA je ideologie. Podobně jako u diskurzu zde existuje rozsáhlé množství variantních vymezení. Kognitivní varianta CDA používá koncept ideologie jako „světonázoru, schematicky organizovaných souborů reprezentací a postojů, které se ustavují s ohledem na sociální realitu, například schémata bělochů vůči černochům “. ${ }^{27} \mathrm{~V}$ rámci lingvisticky orientované

19 Chouliaraki \& Fairclough (1999), srovnej Bourdieu (1991).

20 Srovnej Thompson (1990).

21 Wodak (2008, s. 13).

22 Ingarden (1967), srovnej Bourdieu (2010).

23 Srovnej Eco (2004).

24 Fairclough (1995, s. 187).

25 Gee (2005, 2010), Kress (2010), Kress \& van Leeuwen (2006), Talbot (2007).

26 Wodak (2009), srovnej Mills (1997), Baker (2011, s. 30-31), Andersen (2003).

27 van Dijk (1993, s. 258) cit. in Wodak \& Meyer (2009, s. 8). 
varianty $\mathrm{CDA}^{28}$ je relevantní vymezení ideologie jako „významu ve službě moci“"29, které zdůrazňuje potřebnost vnímat ideologii kriticky (jako namířenou proti někomu, kdo je v diskurzu stigmatizován či z něj vyloučen), ne neutrálně, deskriptivně.

CDA v sobě nese rovněž preference co do volby výzkumných témat. Je orientována primárně na prověřování konkrétních sociálních problémů. Je doporučováno soustředit se na politický nebo mediální diskurz, případně diskurz organizací. V rámci politického nebo mediálního diskurzu se sledují především textové značky xenofobie, populismu, antisemitismu, rasismu nebo nacionalismu, v diskurzech organizací prvky diskriminace (genderové, rasové, atp.). Revize empirické orientace výzkumu na úkor teoretického rozvíjení modelo̊ diskurzu i revize dřive výhradní pozornosti k diskurzu jako nástroji dominance, nikoli subverze a emancipace, je předmětem současných diskuzí v CDA. ${ }^{30}$ Jejich součástí je i prosazování označení „kritická studia diskurzu“ namísto „kritická diskurzivní analýza“"31, které má výše popsanou komplexnost přístupu učinit i v pojmenování explicitní.

\section{Výtky vůči CDA: angažovanost a role diskurzu v sociální realitě}

Výtky vůči CDA se zpravidla zaměřují na její političnost, eklektičnost, předpokládaný vztah diskurzu a reality, nároky na znalosti výzkumníků. Věnovat se budu první z uvedených.

Jak bylo výše uvedeno, CDA zkoumá sociální problémy, které souvisejí s vyloučením či marginalizací určitých jedinců či sociální skupiny z diskurzu. Analytici se zaměřují na kritiku elitních diskurzů, které mocensky asymetrické struktury ve společnosti legitimizují a naturalizují, nověji i na strategie jejich subverze ze strany marginalizovaných. ${ }^{32}$ V obou případech se očekává, že výzkumník bude na straně utlačova-

28 Fairclough (1992), Richardson (2007), srovnej Fowler (1991).

29 Thompson (1990).

30 Srovnej Krzyżanowski \& Forchtner (2016), Angermuller et al. (2014).

31 V češtině se používají označení „kritická diskurzivní analýza“ i „kritická analýza diskurzu“. Podle Schneiderové (2016, s. 14) je lze považovat za oborově specifická synonyma, kdy lingvisté používají spojení analýza diskurzu a sociální vědci diskurzní/diskurzivní analýza.

32 Takto orientované výzkumy lze podle Krzyżanowského a Forchtnera (2016) označit jako positive discourse analysis, srovnej s agendou kulturálních studií např. Chen \& Morley (2006). 
ných. Není to proto, že by taková pozice pravděpodobněji zprostředkovala př́stup k poznání reality. ${ }^{33}$ Ospravedlněno je to Habermasovou teorií veřejné sféry. Ta postuluje, že do diskuze má mít přístup každý, kdo argumentuje racionálně (ve smyslu komunikativní, ne výhradně instrumentální racionality), bez ohledu na jeho/její konkrétní socio-ekonomické postavení, rasu, gender, vzdělání, sexuální orientaci atd. ${ }^{34}$

Angažovanost kritické diskurzivní analýzy iniciuje i kritiku, že politická angažovanost je neslučitelná s nároky na kvalitní vědeckou práci. CDA je údajně vždy více politikou než vědou. ${ }^{35}$ Nicméně CDA nefunguje v pozitivistickém, ale konstruktivistickém paradigmatu, které objektivně existující a objektivně poznatelnou sociální realitu nepředpokládá. ${ }^{36}$ V CDA se podobně jako jinde v kvalitativním výzkumu akcentují jiná kritéria kvality než pozitivisticky chápané hodnoty reprezentativity, reliability a validity. Validace výzkumu je považována za velmi podstatnou, ovšem prostředky, jež ji zajištují, nejsou standardizované postupy analýzy či prověřené koeficienty, ale konstantní komparování. Toto srovnávání probíhá jak na úrovni dílčích zjištění analýzy, která by měla být koherentní a nabízet k př́ípadným rozporům zdůvodnění; dále v rovině srovnávání vlastních zjištění s těmi z jiných výzkumů na podobné téma, a za třetí diskuzí a reinterpretací zjištění s lidmi, kteří nejsou do výzkumu přímo zapojeni. Z kvalitativního výzkumu CDA přejímá důraz na princip sebereflexe. Ze smíšených metod si vypůjčuje princip triangulace.

\section{Metodologie: komunikativní událost, pravidla diskurzu, sebereflexe}

Nyní přejdu od představení CDA k popisu výzkumného postupu, který aplikuju na klip Přemluv bábu. Mezi variantami CDA jsem zvolila př́stup Normana Fairclougha. Jeho operacionalizace diskurzu je podrobná, ${ }^{37}$ přitom relativně srozumitelná a rozsahem zvládnutelná individuálními

33 Fairclough (1992, s. 240), van Dijk (2001, s. 99), Wodak (2009, s. 27), srovnej se standpoint epistemology, např. Ezzy (2002), nebo postoji chicagské školy sociologie, např. Hammersley (2000).

34 Thompson (1990, s. 109-121), Reisigl \& Wodak (2001, s. 70-71), srovnej Herzog (2016).

35 Wodak \& Meyer (2009, s. 33), srovnej Creswell (2007, s. 21-22).

36 Fairclough (2003, s. 14-15), srovnej Hammersley (2000, s. 5).

37 Srovnej van Dijk (2001), Gee (2005, 2010), van Leeuwen (2008). 
výzkumníky, nepracujícími v týmu. ${ }^{8}$ Nedisponuje sice precizovanými nástroji pro práci s vizuálními či audiálními kódy ${ }^{39}$ silná ale je v analýze intertextuality, žánrů a stylů. Postup, se kterým zde pracuji, tedy současně nevystihuje plně mnohotvárnost CDA i ji v jistých aspektech překračuje. Věřím, že bude funkční ilustrací přístupu.

Pro CDA závaznou souvislost mezi textem a kontextem Fairclough vyjadřuje dvojicí komunikativní událost - pravidla diskurzu a trojdimenzionálním modelem diskurzu, který sestává z textu, diskurzivní praxe a sociokulturní praxe. Komunikativní událost ${ }^{40}$ je jednotkou diskurzu, jeho konkrétní manifestací, která je smysluplně ohraničitelná. Jako př́íklady komunikativní události uvádí Fairclough novinový článek, televizní reportáž. V návaznosti na Hallidayovy metafunkce jazyka Fairclough tvrdí, že v každé komunikativní události je specificky reprezentována realita (události, jevy, souvislosti, hodnoty atp.), identity sociálních aktérů (o nichž se v ní mluví a jež na ní participují - novináři, editoři, čtenáři atp.) a vztahy mezi nimi. Tyto tři oblasti uzavírají vnitřní mechanismy diskurzu do přehledných, přitom vzájemně prostupných kategorií ${ }^{41}$ a pomáhají tak jejich zobrazení a porozumění, aniž by nutně činily diskurz jednorozměrným - uchovávají za analytickou stabilizací jeho napětí.

Pravidla, respektive řád diskurzu jsou řetězcem obsahových a formálních prvků, které jsou komunikativním událostem společné a které mohou explicitně či implicitně obsahovat další institucionální či společenské normy, které stanovují, co je dobré/žádoucí a co nevhodné/deviantní atp. ${ }^{42}$ Pravidla diskurzu tak fungují na podkladu hegemonického common sense, nerozporovaných a naturalizovaných představ platných v určité společnosti a zobrazujících, jaká je, či měla by být realita (v kontextu klipu je relevantní třeba představa, jaké situaci je adekvátní nespisovná, místy i vulgární mluva), jak se mají chovat sociální aktéři $\mathrm{v}$ určitých pozicích (tř̌eba mladí lidé, jejichž znalost politiky i praktická zkušenost $\mathrm{s}$ ní je nutně omezená věkem) a jak by měly fungovat vztahy

38 Srovnej Wodak (2001).

39 Srovnej Gee $(2005,2010)$.

40 Fairclough (1992, 1995), Jorgensen \& Phillips (2002, s. 67).

41 Srovnej Gee (2005).

42 Fairclough (1992, 1995), Chouliaraki \& Fairclough (1999), Jorgensen \& Phillips (2002), Baker (2011, s. 86). 
mezi nimi (tř̌eba jestli je v rodině důležitější mít harmonické a právě př́íbuzenským vztahem definované vztahy vnouče-prarodič nebo je možné do nich zahrnout politiku).

Reprezentace reality, reprezentace identit sociálních aktérů a reprezentace vztahů jsou oblasti diskurzu, které komunikativní událost a pravidla diskurzu propojují. $\mathrm{V}$ návaznosti na ně tedy formuluji výzkumné otázky pro analýzu: Jak klip Přemluv bábu reprezentuje politickou situaci v Česku v roce 2010? Jak reprezentuje starší a mladší voliče? Jak reprezentuje vztah mezi nimi? V CDA podobně jako v kvalitativním výzkumu obecněji je preferován induktivní, nebo abduktivní, ne deduktivní př́stup k výzkumu: výzkumník zahajuje svou práci prozkoumáním empirického materiálu, podle něj pak precizuje formulaci výzkumného cíle a výzkumných otázek, dohledává relevantní literaturu, reviduje datový korpus. Postup je tak spíše kruhový, respektive spirálový, nikoli lineární jako v kvantitativním výzkumu; jednotlivé kroky výzkumu nejsou striktně odděleny a není definitivně určena jejich hierarchie a souslednost. Tyto revize si zde dovolím vzhledem $\mathrm{k}$ cíli a rozsahu této stati přeskočit, nicméně upozorňuju na jejich důležitost v plánování designu CDA studie.

Trojdimenzionální model diskurzu vyjadřuje vazbu textu a kontextu, diskurzu a sociální reality příměji a lze jej vnímat i jako schematizovaný návod pro interpretaci. Zobrazuje komunikativní událost jako složenou z textu, diskurzivních praxí a socio-kulturních praxí. ${ }^{43}$ Pro rozbor komunikativní události jako textu Fairclough doporučuje standardní kategorie lingvistiky a doformuluje jejich funkci v sociologické analýze diskurzu. Uvádí, že je možné soustředit se na rozbor lexika, gramatiky, koheze a koherence, intertextuality a interdiskurzivity. Pro každou oblast uvádí množství nástrojů, jejichž výčet neprezentuje jako konečný a který v intencích eklektičnosti a otevřenosti CDA v každé studii mírně variuje. V rozboru lexika doporučuje zaměřit se na volbu slov, jejich význam, metafory a další rétorické tropy. V rozboru gramatiky doporučuje především zkoumat tranzitivitu, trpné a jmenné tvary sloves a modalitu. V rozboru koheze a koherence doporučuje zaměřit se na funkční spojení větných členů a vět, uspořádání textu (horizontální a vertikální struktu-

43 Fairclough (1992), Jorgensen \& Phillips (2002, s. 68-71), Talbot (2007). 
ra), pro dialogické texty přejímá nástroje konverzační analýzy (stř̌idání replik, párové sekvence atp.). $\mathrm{V}$ rozboru intertextuality vymezuje reprezentaci jiného diskurzu, ironii nebo presupozice jako vhodné nástroje, jak posuzovat vnitřní dialogičnost i monologických textů. V rozboru interdiskurzivity upozorňuje na funkci stylu a žánru pro přečtení diskurzu. Jmenované nástroje vysvětlím v analýze, kde je mohu okamžitě doplnit př́klady z klipu.

Posuzujeme-li komunikativní událost jako objekt diskurzivních praxí, soustředíme se na jednání tvůrců či čtenářů textu. Diskurzivní praxe se projevují v interpretačním uzavírání, respektive precizování významu textu: principiálně, má-li slovo či metafora vícero možných výkladů, připočtení diskurzivní praxe - zohlednění informací o situovanosti tvůrců a čtenářù textu v sociální realitě - umožní vybrat mezi nimi ty pravděpodobnější a odmítnout ty hypoteticky možné, ale v konkrétních souvislostech obtížně obhajitelné. Zohlednění diskurzivní praxe zvýznamňuje potřebnost nezkoumat diskurz jen jako strukturu o sobě (vizte poznámku o interním a externím čtení výše). Používáme tytéž nástroje jako pro rozbor textu, ale namísto identifikace a deskripce je v tomto kroku interpretujeme. Pro mapování diskurzivní praxe nabízí CDA nástroje i nad rámec těch, co přecházejí z rozboru textu, jsou ale méně systematizované. Může sem patřit shromažd'ování sociodemografických údajů o empirických autorech a čtenárích, zohlednění jejich profesních rutin nebo recipientských praxí, rekonstruování diskurzivní komunity textu atd.

Vnímáme-li komunikativní událost jako objekt socio-kulturních praxí, zaměřujeme se na předpoklady v diskurzu a na jejich potenciální politické a ideologické důsledky. Pracujeme stále s nástroji z rozboru textu a diskurzivní praxe, jimiž jsme v předchozích krocích identifikované fragmenty popsali a interpretovali. Nyní je explikujeme, tedy zhodnotíme v socio-politickém kontextu. Nástroje z analýzy textu a z analýzy diskurzivních praxí můžeme dále rozšsiřit o koncepty vybrané sociologické grand theory - teorie jednání podle Habermase, Bourdieua, Latoura či jiných. Postup CDA je tedy kumulativní. ${ }^{44}$

Zpracování všech tří oblastí diskurzu je velmi náročné a CDA analytici zpravidla volí intenzivní, ne extenzivní výzkum, studujíce důkladně jed-

44 Wodak (2001, s. 93), srovnej Wengraf (2001), Creswell (2007). 
nu z oblastí analýzy na úkor zbývajících. Klíčová tu znovu je otevřenost CDA a pro kvalitativní výzkum charakteristická důvěra ve výzkumníky jako ty, kteří především by měli posoudit, co s ohledem na výzkumný cíl akcentovat, co odsunout, přičemž tyto své volby by měli patřičně reflektovat. V př́ipadě této analýzy by mohla taková reflexe vypadat takto: Ve své analýze jsem upřednostnila rozbor prostřednictvím lingvistických kategorií a koncepty sociologické zohledňovala minimálně. Odpovídá to více zadání, podle kterého píšu, i mým pedagogickým zkušenostem, ačkoli průpravu mám jak lingvistickou, tak sociologickou. K prvnímu, cílem studie bylo představit a ilustrovat rozbor textu podle vybrané tradice a, jak jsem uvedla, slabší teoretická báze se v CDA začala reflektovat relativně nedávno. $\mathrm{K}$ druhému, učím $\mathrm{CDA}$ a vedu takto orientované závěrečné práce zhruba sedm let a vysvětlovat lingvistické kategorie považuju za snazší (navzdory pravidelně se opakujícímu zpěčování studentů vracet se třeba $\mathrm{k}$ větným rozborům) i odpovědnější (umožňuje lépe se bránit přetrvávající kritice „fabulace“ v kvalitativním výzkumu, vedené z nepř́liliš progresivních kvantitativních pozic). Sociologickou, respektive sociologii a literární teorii kombinující interpretaci diskurzu osobně považuju za zajímavější, časově však velmi náročnou - tedy nevhodnou tomuto úkolu. Záblesky této pro mne zatím nehotové syntézy lze v rozboru zahlédnout. Volba klipu je podobně jako struktura stati dána zadáním. Sama bych si klip nevybrala, protože - bezelstně - mi připadal trochu hloupý. Možná kdybych vyrůstala v liberálním prostředí, žila v Praze a znala Dejvické divadlo, uvažovala bych už úvodem jinak. Proces jeho rozboru přesto hodnotím jako pro mne užitečný a inspirativní, především proto, že se pohybuje na rozmezí mediálního a popkulturního diskurzu.

\section{Analýza: proč přemlouvat báby a dědy}

Tři stupně rozboru komunikativní události je žádoucí provádět odděleně, prezentuji je ale současně, synteticky. Kostru tvoří kategorie definované pro rozbor textu. 


\section{Lexikum}

V rozboru lexika textu Fairclough doporučuje sledovat volbu a význam slov. ${ }^{45}$ Jejich využití v analýze ilustruju na slovech „přemluv“ a „bábu“. Jsou v klipu velmi frekventovaná (pět, respektive tři výskyty), umístěna v prioritních pozicích (název, úvodní a závěrečná replika) a byla vyhodnocena jako klíčová po srovnání s referenčním korpusem ${ }^{46}$. Nocionální význam slova „přemluvit“ je podle Slovníku spisovné češtiny „mluvením, uvedením důvodů přimět, pohnout““.47 To celkem koresponduje s ex post proklamací, že smyslem videa bylo otevřít diskuzi. Chci-li však tvrdit, že toto souznění není pouze nahodilé a povrchové, potřebuji vyzkoušet funkční nenahraditelnost slova. Respektive, potřebuju rekonstruovat potenciální paradigmatické řady a prověřit, zda se výměnou slova „přemluv“ za jiné celkový význam videa zásadněji posune či nikoli. Začnu ,praktickými‘ způsoby komutace, totiž slovy „zabij“ a „oklam/ojeb“, které byly použity v parodiích ${ }^{48}$ klipu. Funkci původního slova z hlediska gramatiky (2. os. sg. imperativu, váže k sobě jméno v akuzativu) či stylu (vulgarismus v druhém případě) sice plní, obsahově - věcně však přenositelná nejsou. Vkládala by do klipu další rozpory k těm již existujícím. Ačkoli výmluvně předznačují některé konkrétní divácké způsoby interpretace klipu, jsou přehnané.

Uvažuji tedy o bližším paradigmatu takových sloves, která by zachovávala akcent na diskurzivnost jednání i bez aspektu přesvědčování, tedy například „řekni“, „pověz“49. To umožňuje ptát se, zda je proklamativně žádoucí přesvědčování starších mladšími a jejich zdůvodňování, proč nemají volit levici, textem klipu podpořeno nebo ne. Issová s Mádlem několik důvodů uvádějí - například „levice nadělá dluhy a zatímco voni

45 Fairclough (1992, s. 185-94).

46 Pracovala jsem zde s dílčí bází Českého národního korpusu KWords, kde vstupním textem byl přepis klipu a jako referenční korpus zvolen SYN2010. SYN2010 jsem vybrala, protože se skládá z textů z let 2005-2009 a z dostupných je tak časově nejblíže rozebíranému klipu. Ideální není, že zachycuje stav psaného, nikoli mluveného jazyka, věřím však, že dílčí poznatky získané z KWords analýzy jsou zde užitečné a podepřené i jinak. Pro srovnání relativní frekvence slov ve zkoumaném textu s relativní frekvencí týchž v referenčním korpusu jsem použila kombinaci testů chí2 log-likelihood. (Cvrček \& Vondřička, 2013).

47 AV ČR (C) 2008-2018, heslo „přemluvit“).

48 Srovnej např. [Rubeš \& Stýblo] (2010).

49 Lingea (2012, heslo „přemluv“). 
si v klidu umřou, tak my je pak budeme do konce života splácet“. Zdá se ale, že jsou to vágní (metonymie „levice“), nepodložené (presupozice ,levicová politika je žití na dluh'), emocionálně nepřiměřené (,voni si v klidu umřou“) a hyperbolizované („do konce života splácet“) předpoklady o budoucnosti, které jsou jako fakta pouze prezentovány. Takže, nemají protagonisté trochu zcestné představy o povaze politické - a občanské diskuze? Nebo přijímají praxi, že rozpravu je potřeba zahájit provokací, protože tak se podaří zaangažovat víc lidí a čas na podrobnější argumentování pozic bude později?

Druhé klíčové slovo klipu je „bába“. U předchozího jsem se věnovala volbě slova a jeho funkční nahraditelnosti, zde mi jde o významový potenciál. Podle Slovníku spisovné češtiny jde o hovorové označení „stařeny“, případně hanlivé pojmenování „nepř́ijemné, zlé ženy, ženské.“5o Pokud slovníkový význam přijmu jako totožný se situovaným významem slova v klipu, otevírá se interpretace, že video je velmi neuctivé ke starším voličům, a je to mimo jiné zřejmé z toho, jak je tituluje. Na druhou stranu, v klipu figuruje i podoba slova „babička“ a navíc v paralelní dvojici „děda“ - „dědeček“ jsou obě slova bezpříznaková, stylově neutrální. Dominantní pozici v klipu má navíc Issová, nikoli Mádl, což není úplně standardní rozdělení genderových rolí. Použití slova bába namísto babičky takto může být i pokus o rekódování identity starší ženy, který ji namísto urážení zrovnoprávňuje. Odstranění deminutivní koncovky může signalizovat pokus zrušit příznak roztomilosti, aniž by to nutně vedlo ke zhrubnutí (srovnej mediální používání slov lesba - lesbička a neexistence zdrobnělého ekvivalentu pro gaye).

V rozboru lexika Fairclough dále doporučuje zabývat se rétorickými tropy, především metaforami a metonymiemi..$^{51}$ Jako metonymii ${ }^{2}$ rozeberu další klíčové slovo textu, levice. Zdá se, že ve videu Přemluv bábu je metonymie použita pro rychlejší charakterizaci a efektivnější polarizaci diskurzu. „Levice“ (celek) je spojována s komunisty (trojí použití slova) a socialisty (jedno použití, které je ve slučovacím vztahu s komunisty; oboje reprezentuje části). Přejímá tak jejich stereotypizovaně špatné vlastnosti a zpětně je potvrzuje (levice „nadělá dluhy“, ,nechce řešit pro-

50 AV ČR (C) 2008-2018, heslo „bába“).

51 Fairclough (1992, s. 194-198).

52 Srovnej Lakoff \& Johnson (2002), Goatly (2007). 
blémy s důchody“ a „nepřipustí školný“). Přestože výčet potenciálních reprezentantů levice v klipu není úplný (chybějí např́klad liberálové, kteří jsou v Česku častěji spojováni s pravicí (sic)) ani věcně adekvátní (,socialisté“ není synonymní „sociálním demokratům“, přestože je takto v politickém i mediálním diskurzu občas používáno), jako definitivní působí. Zajímavé je, že paralelní výčet reprezentantů pro pravici v klipu přítomný není. Po vzoru předchozího by pravice mohla být spojována třeba s neoliberály nebo se znovu ne zcela adekvátními pojmenováními kapitalisté či konzervativci. Zůstává však abstraktní; může se vzhledem k tomu jevit i jako nadosobní, lidskými chybami nezatîžená. Žádné atributy jí přisouzeny nejsou: je předpokládaným opakem levice. Vytvoření binární opozice mezi pravicí a levicí a dehonestování levice ji má prostou silou protikladu vyzvednout. I kdybychom přistoupili na implikaci, že pravice ,nenadělá dluhy', je to předpoklad, nikoli fakt, a jeho návaznost na pravicovou politiku je vágní. Spoléhat na binární logiku je znovu faul, přestože možná kognitivně svůdný, protože nepř́pustně zjednodušuje realitu - pomíjí otázku politického středu, dílčí prostupnost pravicových a levicových řešení sociálních problémů atd.

Klíčové slovo levice funguje i homonymicky (zajímavé ve vztahu k významovému potenciálu slova): levice jako politická strana a levice jako část lidského těla. Issová říká: „Pravou ruku všude na světě lidi používaj k pozdravu nebo k přijímání potravy a levou rukou si lidi všude na světe vytíraj zadek.“ Mádl sice kontruje (k tomu dál), Issová nicméně dodává: „No hlavně když budete volit levici, tak si pak levice vytře zadek s váma.“ Automatické sloučení vlastností v homonymních dvojicích potvrzuje hodnocení, která byla té či oné části politického spektra přisouzena i metonymicky. Že protagonisté klipu ze zvukové podobnosti vyvozují podobnost významovou, je znovu možná efektní přesmyčkou, významovou příbuznost však neimplikuje, maximálně konstruuje dojem její žádoucnosti. Vzniklý významový amalgám tak zůstává věcně nesprávný.

\section{Gramatika}

V rozboru gramatických jevů v textu se kritičtí analytici diskurzu soustředí nejčastěji na tranzitivitu a modalitu. Přestože angličtina a češ- 
tina přistupují $\mathrm{k}$ oběma trochu jinak, přejmu zde kategorie angličtiny s odůvodněním, že jejich vazba na interpretaci v CDA je přímější. Při posuzování tranzitivity se tak soustředím na to, kterým aktérům je přisouzena role agentu, respektive patientu ${ }^{53}$. Objevují se zde další doklady o polarizaci aktérů v textu. Rozdělení se tentokrát netýká primárně levice a pravice, ale jejich voličů. Distribuce „dobra a zla“však zůstává podobná a umožňuje proto snadné budování paralel, tím i opětovné stvrzování hodnotícího příznaku, přestože věcně je takové přenášení charakteristik nepodložené. Na jedné straně (pravicové) stojí mladí voliči (a Issová s Mádlem), na druhé (levicové) jejich starší př́íbuzní. Oběma je celkem rovnoměrně připisována aktivní i pasivní role, velmi se však liší, v čem. Vztah mezi nimi není představovaný, ale existující, kde rozhodnutím aktérů na jedné straně trpí ta druhá a vice versa. Zatímco mladí mají přemlouváním starších „změnit osud týhle země“ (role agentu), starší předpokládaně sedí doma a čekají na návštěvu svých vnoučat, která jsou pro ně „to nejdůležitější na světě“ (role patientu, respektive beneficientu). Starší sice „volej“ a „argumentujou tím, že volí levici kvůli vám“ (role agentu), ale sledují přitom bud' krátkodobé cíle (,jestli někdo volí levici kvưli 30 Kč poplatku, dobře, ale je to teda dost sobecký rozhodnutí, který třeba mě poškodí"), které jsou s jejich vysvětlením de facto v rozporu, nebo se údajně snadno nechají ovlivnit politickou rétorikou, která je zobrazována jako krátkozraká, sic aktuálně lákavá („Levice nepřipustí školný, oni totiž rádi hlásaj, že to jakože znepř́istupní vzdělání chudším. Jenže to je úplná blbost. Naopak."). Mladší tedy aktivitami starších trpí („Vzdělávání u nás v Čechách není moc dobrý“), nebo nevyhnutelně budou trpět („Navíc levice nechce řešit problémy s důchody, a pokud nedojde k reformě, tak ve státní kase nebudou na důchody peníze“, „pokud nedokážeme motivovat školy, aby s tím něco dělaly, tak nám ty nejlepší studenti budou odcházet do zahraničí"). Mladší se tak ocitají v roli patientu. Prohlédneme-li si postupně budované identity aktérů a vztahů mezi nimi, je zřejmé, že herci používají unáhlená zobecnění ${ }^{54}$. Znovu tak zakládají zdánlivě nerozpojitelné významové amalgámy, kde charakteristika ,starší‘ automaticky přechází do dalších jako ,volí levici‘, ,žije na

53 Fairclough (1992, 2003), Fowler (1991), Richardson (2007), srovnej Karlík (2003, s. 384-388). 54 Srovnej Richardson (2007, s. 169-170). 
vesnici“, ,má selektivní pamět‘ , ,argumentuje zcestně či ,nemá plnohodnotnou náplň života a čeká, až mu den rozjasní návštěva vnoučat‘. Ty přitom nejsou vysvětleny a potřeba je zdůvodňovat vzhledem k deklarativnímu tónu, dominantnímu v celém klipu, opakováním a postupným vrstvením zaniká.

Na poznámku o deklaratornosti navazuji pozorností CDA k modalitě. V jejím určování jsem použila kategorizaci Fowlera ${ }^{55}$, rozlišující mezi modalitou pravdy, povinnosti, povolení a žádoucnosti. Modalita pravdy předpokládá oznamovací slovesný způsob - ten je v klipu nejfrekventovanější. Protože jednotlivá prohlášení nejsou upravena prostřednictvím modálních částic, modálních sloves či eufemismů (např. „volej levici“ namísto alternativního ,většinou volí levici', ,mohou volit levici', ,inklinují spíš k levici' atp.), mohou snadněji působit jako pravdivá. Modalita povolení v textu použita není, vztah mezi staršími a mladšími tedy není reprezentován jako direktivní, mocensky jednosměrný. To konvenuje s předchozím - každá skupina může způsobovat trápení té druhé. Chybí nějaký oběma nadřazený arbitr, který by něco $\mathrm{z}$ toho povoloval či zakazoval. Modalita povinnosti je rovněž relativně slabá. Mladí mají jistou morální povinnost („Kdybyste věděli, že můžete změnit osud týhle zeme““), vazba k ,zemi', potažmo širšímu společenství, je nicméně explicitně zmíněna pouze úvodem a z dalších replik klipu se zdá, že jde spíš o povinnost a výhodnost osobní (nekvalitní školy, žádný důchod). Modalita žádoucnosti je zřetelnější (přemluv bábu a dědu, aby nevolili levici), podobně u předchozí není úplně jasné, kdo z toho bude profitovat.

Pomoci v interpretaci, pro koho je volit „nějakou novou pravicovou stranu“ vlastně žádoucí, by hypoteticky mohl další z nástrojů pro rozbor lexika, a to použivání deiktických a přivlastňovacích zájmen ${ }^{56}$. Je zajímavé, že ve vztahu ke starším použivají Issová a Mádl osobní posesivní zájmena („To můžou bejt lidi z vaší rodiny. To může bejt vaše teta, váš strejda, vaše babička...“, „Kdybyste věděli, že můžete změnit osud týhle země tím, že navštívíte svoje prarodiče"). Vztah mezi staršími a mladšími je tak limitován okruhem širší rodiny. Apeluje se ale i s důrazem na „osud týhle země“. Vztah země a voličů ovšem zůstává implicitní, netematizovaný.

55 Fowler (1991, s. 85-87).

56 Fairclough (2003, s. 145), srovnej Billig (1995). 
V rozboru gramatiky Fairclough dále doporučuje věnovat se použivání pasivizovaných či nominalizovaných tvarů sloves, ${ }^{57}$ které věty deagentizují a mohou působit ideologicky tím, že od aktérů odnímají zodpovědnost za určitá rozhodnutí či jednání..$^{8}$ Respektive, aktéry zneviditelňují a rozhodnutí se tak mohou jevit objektivněji, nevyhnutelněji. Pasivizace a nominalizace v klipu však moc používány nejsou. Vzhledem k polarizaci v klipu, kdy viník špatných rozhodnutí je označen opakovaně a přímo, i vzhledem k stylové neformálnosti (vizte dál rozbor interdiskurzivity) je to celkem pochopitelné.

\section{Koheze a koherence textu}

Třetí prríčkou v rozboru textu je podle Fairclougha vnitřní koheze textu, koherence a způsob výstavby (narace, uspořádání). ${ }^{59}$ Předmětem rozboru koheze a koherence je prověřování formální a obsahové soudržnosti textu. ${ }^{60}$ Užitečné jsou zde spojky, které mohou implikovat návaznosti časové, prostorové či kauzální; dále anafory a katafory v textu (slova opakovaná či při zachování významu nahrazovaná deiktickými zájmeny či příslovci). Je možné zahrnout sem i aktuální větné členění a věnovat se rozboru tematických a rematických částí výpovědín ${ }^{61}$ Ze spojek jsou v klipu používány takové, co vytvářejí kauzální spojení - krom spojek implikujících př́íčinný (spojka protože) nebo důvodový (totiž) poměr vět sem zařazuji i takové, co odkazují k podmínkám (pokud, jestli, když), nebo vyvozují důsledky (takže, tak). Podepírají vztah mezi aktéry, popsaný výše v souvislosti s tranzitivitou, časově ho zakotvují a rozdělují na fáze lineárního procesu, jejichž návaznost je prezentována jako nevyhnutelná: „Jestli v týhle zemi zvítězí u přištích voleb levice, tak za to budou moct starý lidi, protože to jsou ty, který levici volej.“ A „teda pokud nejste úplně [vypípáno]“, pojedete je přemlouvat - protože jinak je vám přisouzena identita takových sprostáků, že ji ani v nespisovném klipu

57 Srovnej van Dijk (2001, s. 108), van Leeuwen (2008, s. 30), Fowler (1991, s. 79-80), Thompson (1990, s. 66).

58 Srovnej Karlík (2003, s. 522-533).

59 Fairclough (1992, s. 77, 1995, s. 121-124, 2001, s. 108).

6o Srovnej Nekula (2003b, s. 681-698).

61 Srovnej Nekula (2003a, s. 633-645). 
nelze vyslovit, a budete tím i dál do budoucna jistě trpět (dluhy, žádné důchody, nekvalitní školství).

Rozbor aktuálního větného členění ilustruji na větě: „Protože levice nadělá dluhy a zatímco voni si v klidu umřou, tak my je pak budeme do konce života splácet.“ První část věty má vyjadřovat skutečnosti, které jsou považovány za obecně známé. Tím se presupozice „levice nadělá dluhy" znovu (viz analýza modality) prezentuje jako platné shrnutí. Zbylé dvě věty jako rematická část výpovědi mají přinášet nové informace. Diváky varují. Jsou formulovány spíš hyperbolicky než direktivně. Spolu s neformálností celého klipu tak mohou naznačovat žádoucnost ideové sjednocenosti mezi protagonisty a diváky klipu, či ji postulovat jako reálnou (díky performativní funkci jazyka, jež je ve Faircloughově definici diskurzu jako sociální praxe implicitní). Vzájemný souhlas je jako tvůrci preferovaný vztah explicitně předznamenán v úvodu klipu („Kdybyste věděli, (...), zajeli byste za nima? No jasně, že jo.").

Způsob výstavby textu lze posoudit optikou konverzační analýzy, z níž Fairclough přebírá rozbor párových sekvencíbi ${ }^{\text {. Pozornosti hodné }}$ je tak třeba dodržování rovnováhy při nastolování témat konverzace či slušnost a úplnost při reagování na repliky druhého (srovnej s Griceovými konverzačními maximami). Dominantnější roli má Martha Issová. V klipu je několik neporozumění mezi ní a Mádlem. První z nich:

M.I.: „(...) Jestli v týhle zemi zvítězí u prrišśích voleb levice, tak za to budou moct starý lidi, protože to jsou ty, který levici volej. To můžou bejt lidi z vaší rodiny. To může bejt vaše teta, váš strejda, vaše babička..."

J.M.: „...váš děda.“

M.I.: „No. A většinou ty lidi bydlej na vesnici. Jak je to možný?"

J.M.: „Prostě se tam narodili!“

M.I.: „Ne, jakje možný, že tu levici volej?“

Mádlovo neporozumění vzniká vytvořením krátkého propojení otázky $\mathrm{s}$ bezprostředně předcházející větou, nikoli vzdálenějším úsekem. Mož-

62 Fairclough (1992, s. 152-157). 
ná to měl být humorný prvek klipu. Při porovnání s tezí o „tzv. selektivní paměti“ starších i s kritizovanou krátkozrakostí jejich jednání to ale působí zvláštně (haní něco, co sám evidentně dělá) a mělo by snižovat kredibilitu klipu. Funkce poznámky, že starší lidé většinou bydlí na vesnici, je nejasná. Na jedné straně může sloužit $\mathrm{k}$ delegitimizaci starších: lze ji dát dohromady s používáním jiných binárních opozic v klipu a navrhnout, že herci používají svému diskurzu vnější mýty vesnice a města, kde město je asociováno s intelektuální prací a kosmopolitností a vesnice s manuální prací a uzavřeností. Zároveň však ve srovnání s jinými není použita opakovaně, což by nahrávalo tomu, že je to mikro vtip, navíc ironizovaný. Issová si Mádlova neporozumění všímá a opravuje ho. V dalších případech však nepochopení ignoruje.

M.I.: „... přesvědčit je, že mají volit pravici.“

J.M.: Nebo neеlakou novou stranu."

M.I.: ,No néjakou novou pravicovou stranua pravice je tohle."

J.M.: „No ale pro ně je to vobráceně."

M.I.: „Pravou ruku všude na světě lidi používaj k pozdravu nebo k prijímání potravy a levou rukou si lidi všude na světe vytíraj zadek."

J.M.: „No v některých zemích....”.

M.I.: „No, hlavně $k d y z ̌$ budete volit levici, tak si pak levice vytře zadek s váma.“

To může mít znovu komickou funkci a činit video atraktivnějším (ve volné parafrázi komediálních dvojic). Vzájemná nepochopení jsou př́tomná v první části klipu, která může být navrhnuta s ohledem na upoutání největší možné divácké pozornosti. $\mathrm{V}$ další části, kde herci přesvědčují o špatnosti levice, jsou jejich repliky konzistentní a bez přerušení.

\section{Intertextualita}

Poslední úrovní analýzy textu je rozbor intertextuality a interdiskurzivity. Pro intertextualitu Fairclough určuje nástroje reprezentace diskurzu, presupozice, negace, metadiskurz a ironie. Zajímá-li nás re- 
prezentace diskurzu, ptáme se, jaký diskurz je $\mathrm{v}$ analyzovaném textu citován či parafrázován, $v$ př́padě parafráze dál studujeme, zda je tato jeho rekontextualizace adekvátní a úplná. V klipu Přemluv bábu jsou reprezentovány diskurzy starších a mladších voličů (koho volí a proč) či diskurzy levice a pravice (jaká je politika a rétorika stran). Viděli jsme výše, že jejich reformulace $\mathrm{v}$ klipu jsou zkratkovité a neúplné. Presupozice jsou implicitními předpoklady zkoumaného textu; jsou gramatické či logické. ${ }^{63}$ Stopování presupozic provazuji s rozborem aktuálního větného členění a analýzou modality ${ }^{64}$. Ilustruji na pokusu herců rekonstruovat, proč starší volí levici, což je souvislost ne zcela v nesouladu s analýzami voličského chování65, nicméně v banalizované, ergo málo adekvátní formě. Stejně tak vysvětlení („Starý lidi mají totiž tzv. selektivní pamět. To znamená, že si pamatujou jenom ty hezký věci.") není zcela irelevantní, je však neúplné (mohou mít jiné důvody, proč volit levici), ne zcela správné (selektivní pamět neznamená nutně pamatovat si ,jen ty hezký věci“, ale zážitky a zkušenosti formativní, a to i silně negativní) a nespravedlivé (percepční filtrování není netypické ani pro mladší lidi). Konstrukci daných souvislostí (koho starší volí a proč) lze hodnotit jako presupozice, představované jako fakta.

Negace odkazují k tomu, co je v klipu odmítnuto - které reprezentované diskurzy jsou označeny jako lživé či jaká jejich východiska (presupozice reprezentovaných diskurzů) jsou uvedena jako iluzorní či nepodložená. Zde je jako falešný zobrazován diskurz levice (implicitně: zajímá ji podíl u moci nyní, nikoli budoucnost země) i diskurz starších voličù (nechají se snadno zmanipulovat a jejich obhajoba volby levice je nedomyšlená, proto pouze formální). Za metadiskurz - vyjádření distance mluvčího vůči tomu, co říká - je možné považovat sebezesměšňování. Není úplně jasné, zda je projevem autorské sebereflexe nebo zábavným prvkem. Podobně ironie - chyby a vizuální i verbální narušování jednoznačnosti mediovaného sdělení lze hodnotit jako výraz sebeironie. Mnohá hyperbolizovaná vyjádření by rovněž bylo možné dekódovat jako projev sebeironie (ale samozřejmě i hysterie).

63 Culler (1981).

64 Fairclough (1993, s. 161).

65 Linek \& Lyons (2013). 


\section{Interdiskurzivita}

Interdiskurzivita pro Fairclougha znamená zahrnout do rozboru styl a žánr textu. ${ }^{66} \mathrm{Z}$ hlediska stylu je nejzřetelnější neformálnost, patrná ve volbě jazyka (nespisovná varianta češtiny), ve stylizaci protagonistů i prostředí (volnočasové oblečení, obývák). Hovorovost až nespisovnost je sice pro mluvené texty charakteristická, ${ }^{67} \mathrm{v}$ politickém diskurzu se nicméně standardně používá spisovná varianta jazyka jakožto naplňující reprezentativní funkci jazyka - a to i v mluvených projevech, kde jsou porušení normy zpravidla bezděčná, mluvčími kontrolovaná, případně i korigovaná. Issová a Mádl se oficiálně působit nesnaží. To může indikovat nepřipravenost, nebo pokus normy politického diskurzu porušovat. Nepřipravenost nepředpokládám. Přestože herci mluvili o spontánnosti videa, je zřetelné, že prošlo aspoň minimální editací. Na přípravu obsahovou usuzuji třeba z inspirace klipem Silvermanové nebo z promítání ilustrativních obrázků k řeči (přestože jsou často pomýlené, asi nejsou vyhledávány až v průběhu natáčení klipu). Pravděpodobnější je tedy úmysl porušit standardy politického diskurzu. Způsob tohoto porušování přitom celkem konvenuje s tím, co Reisigl a Wodak na rétorice Jorga Haidera označují jako populismus (promluvy, „které obsahují prvky volebního projevu i hospodské debaty“) ${ }^{68}$. Nicméně, žádný z tvůrců videa se v politice neangažuje a neangažoval. Jejich apel (explicitní či ex post postulovaný) - nevolte levici a nedovolte návrat komunismu - žádnému z nich bezprostřední a pouze osobní výhodu nepřináší. Ani žánrově jejich klip není předvolebním projevem, ale virálním videem, připomínajícím tvorbu youtuberů či komunikaci mileniálo̊.

Tím přecházím k druhé kategorii interdiskurzivity, žánru. Fairclough jeho definici modifikuje, aby zohledňovala pojetí diskurzu jako sociální praxe i jeho situační zakotvenost. ${ }^{69}$ Chápe jej jako „konvencionalizovaný, více či méně schematizovaný zpo̊sob použití jazyka asociovaný s určitým druhem aktivity“. ${ }^{70}$ Aktivitou - jednáním, jež klip uskutečňuje

66 Fairclough (1992, 2001), srovnej Wodak (2001).

67 Srovnej Krčmová \& Chloupek (2017).

68 Reisigl \& Wodak (2008, s. 38).

69 Srovnej Wodak (2001, s. 66).

70 Fairclough (1995, s. 14). 
- je informovat a pobavit. Herci přicházejí s určitou představou o realitě (staří volí levici a pro osud téhle země je to nevýhodné), vysvětlují její motivovanost a představují potenciálně nebezpečné důsledky, zůstane-li nereflektována a proto i opakovaně uskutečňována. Nepodloženost, fragmentárnost a neúplnost mediovaných informací, demonstrované dosavadním rozborem, vypovídá o jejich kvalitě, nemaže však to, že o informace, tedy i o aktivitu informování jde. Spolu s jinými prvky klipu jsou zároveň zezábavňovány. Protagonisté $\mathrm{k}$ předávaným informacím nepřistupují z pozice experta, ale laika, ne mentorsky a seriózně, ale nespolehlivě a komicky. Opakovaná vzájemná nepochopení, několikeré nesprávné obrazové ilustrace $\mathrm{k}$ pronášenému, ale i až směšně naléhavé výrazy ve tvářích, urputná touha znázornit i nejbanálnější věci (např́íklad gestikulace Issové, když ř́ká, že pravou rukou se lidé zdraví či jedí) a v posledku děravé vysvětlování, to vše lze vnímat jako zezábavňování klipu i na úkor jeho protagonistů. K propojeným aktivitám informovat a bavit hledám podle Faircloughova doporučení konvence či schémata řeči, která by jim byla adekvátní.

Vyjádření konvencí nacházím $\mathrm{v}$ pravidlech žánrové hybridizace ${ }^{71}$, brikoláže, parodie, multimodality, s nimiž i jinak než jazykem klip koresponduje. Jejich naplnění předznamenává a ulehčuje volba virálního videa jako svébytného, byt málo teoretizovaného žánru pozdní modernity. Parodický je klip v opakovaně špatném používání obrázků, které jsou v rozporu s řečí (tř̌eba repliku, že pro prarodiče „vnoučata jsou to nejdůležitější na světě“, ilustrují fotkou Josefa Fritzla, který 24 let věznil vlastní dceru a zplodil s ní sedm dětí). Může jít o parodii politických klipů či instruktážních videí; nebo to lze spolu se sebeironií číst jako upozorňování na možnost vlastního nespolehlivého vyprávění. Multimodální je klip třeba kombinováním hraného a kresleného obrazu či užitím zvuků napodobujících reálné - spláchnutí záchodu - i počítačem generovaných - hudba v pozadí. Brikoláží je, protože slepuje fotografie, obrázky a zvuky, jejich původ je neznámý a není ani potřeba jej znát (srovnej $\mathrm{s}$ dřívějším používáním aluzí $\mathrm{v}$ literatuře či výtvarném umění), a začleňuje je do natáčeného. Žánrově hybridní je, protože slučuje politickou řeč, přednášku s názornými demonstracemi a komediální skeč. Vzhle-

71 Fairclough (1992, s. 202, 2003, s. 22), Chouliaraki \& Fairclough (1999), Talbot (2007). 
dem k žánrovému zařazení navrhuji klip interpretovat jako postmoderní aktualizaci politického diskurzu.

Pravidla postmoderní estetiky jsou dnes celkem stabilizovanou součástí popkulturní řeči filmů, seriálů, hudebních videoklipů atd..$^{72}$ Uplatňují se i v diskurzu reklamním či politickém, kde ale může být jejich použití ošidné právě kvůli významové ambivalenci, kterou propouštějí a vzhledem ke které se mohou interpretačně svým tvůrcům snadno vysmeknout a působit i proti nim). Totéž se stalo klipu Přemluv bábu. A pokud zdůvodnění estetikou postmodernismu, tedy i nutné přehodnocení předešlého vzhledem k žánrovému zařazení, nepřijmeme, je i celkem jasné proč. Aktivity herců pak totiž nejsou rozpoznány jako parodické, které s převracením i hyperbolizací počítají133, ale jako populisticky žoviální a nepoučené. Přesto si myslím, že pokud Mádl hovořil o tom, že klip byl daleko promyšlenější a většina diváků ho vnímala povrchně, ${ }^{74}$ mohl referovat právě $\mathrm{k}$ tomuto. Issová ke klipu v rozhovoru v rámci Sametového speciálu DVTV a spolku Díky, že můžem $\mathrm{k}$ výročí 17. Listopadu řekla: „především to byl pokus o humor a humor, jak víme, stejně jako Sovětský svaz nemá hranice."75

\section{Shrnutí a diskuze}

Průběžně nasbíranou evidenci k výzkumným otázkám shrnu spolu s jejím rekódováním po zohlednění žánru videa a revizí těch bodů rozboru, které na nižších rovinách zůstávaly interpretačně rozpolcené. Žánru přisuzuji pozici interpretačně silnou natolik, že předchozí, i vícestranně potvrzené závěry dokáže znovu zpochybnit, protože žánr je důležitý v předdefinování toho, co ve sdělení vůbec může být vysloveno a jak. Př́pustné či preferované žánry přitom indikují pravidla společenského diskurzu, mohou je i trochu předbíhat. ${ }^{76}$ Virální video jsem výše zařadila jako žánr těžící z postmoderní estetiky. Spojitost mezi postmoder-

72 Srovnej Docker (1994), McRobbie (2003), Featherstone (2007), Talbot (2007).

73 Srovnej Docker (1994, s. 168-218, 280-284).

74 Hejdová (2016).

75 Drtinová (2018).

76 Srovnej Lyotard (1993, s. 28). 
nismem jako způsobem myšlení a pozdní modernitou77 jako fází vývoje společnosti předpokládám.

Rozporuplně se jevila reprezentace vztahu mladších a starších (třetí výzkumná otázka). Na jedné straně bylo jako normální zobrazováno zajímat se o členy své rodiny (apel na přemlouvání starších př́íbuzných, ne třeba starších kolegů $\mathrm{v}$ práci nebo přesvědčování kamarádi̊, aby šli volit a volbu starších tak přebili; pokus porozumět motivacím starších, byt fragmentární a povrchový; proklamativně láskyplný vztah prarodičů a vnoučat, sic explicitně takto jen z jedné strany). Na druhé straně jsou starší opakovaně dehonestováni (přidělovanými charakteristikami, parafrázovaně prostoduchým způsobem myšlení a jednání), což mladým divákům klipu umožňuje přisvojit si pozici moudřejších, tedy pozici moci. Rozepsaný rozpor byl vidět i v klíčovém slovu „bába“, které lze interpretovat jako vyjádření respektu, i indicii výsměchu.

O reprezentaci vztahu mezi aktéry může parciálně vypovídat i pro ně zkonstruovaná identita, poskládaná z přisouzených vlastností, činností či hodnot (druhá výzkumná otázka). O starších z klipu víme, že volí levici, bydlí na vesnici, zapomínají (mají selektivní pamět') a milují svá vnoučata. O mladších víme, že přesvědčují druhé, když jim o něco jde (Issová a Mádl natáčejí instruktivní klip, diváci jistě pojedou za prarodiči, pokud vědí, že tím mohou změnit osud země), jsou neformální (styl videa), vzdělaní (Issová a Mádl poznají, když jim promítnou nesprávné ilustrativní obrázky), ale leckdy i povrchní (kvalita předkládaných tvrzení, očekávaná potřeba, tedy i nabídka bezprostřední odměny), rádi se baví (humorné aspekty klipu, slibovanou rychlou odměnou je porno). Obě zkonstruované identity jsou prokazatelně neúplné a místy i věcně neadekvátní. Srovnáme-li v tomto momentu, kdy nezohledňujeme žánr klipu, reprezentaci identit a vzájemného vztahu, zdá se jako pravděpodobnější, že mladší se starším vysmívají.

Přistoupíme-li s ohledem na pravidla postmoderní estetiky na výklad, že dílčí (a nelze bezpečně rozhodnout, které) aspekty identit i vztahu mohou být hyperbolizací a takto parodií ve společnosti existujících předsudků, představa o asymetrickém a výsměšném vztahu už tak samozřejmá není. Jako potenciálně relevantní se vrací ta druhá, podle níž hojné

77 Giddens (2003), Wagner (1994). 
úšklebky důležitost dobrých rodinných vztahů nepopírají a nezamezují jim, a to především proto, že jsou směřovány na obě strany - na starší $\mathrm{v}$ rovině obsahu, na mladší přes formální prvky, tedy styl a způsob zpracování. Lze ji částečně podložit teoreticky - Fairclough ${ }^{78}$ píše o demokratizaci jako o jedné z podstatných tendencí pozdně moderního diskurzu a odkazuje tak k rušení značek strukturních nerovností v jazyce a jeho větší otevřenosti, která může delegitimizovat dříve spíš hierarchizované vztahy v sociálních institucích, tedy i v rodině. Konstatovaná demokratizace nezaručuje změnu sociálních vztahů a může být i maskováním naopak utužování již platných struktur. Demokratizace je přesto funkční princip postmoderní estetiky a v žánrové hybridizaci a brikoláži je definitorický. Z hlediska posuzování toho, jak je reprezentován vztah mezi staršími a mladšími, mi proto nepřipadá úplně nepodstatný.

Druhá nejasnost se týkala definice odměny a toho, ziskem pro koho vlastně je. Je dílčím prvkem reprezentace reality v klipu (první výzkumná otázka), která kompletněji postuluje, že ve volbách 2010 se rozhoduje o osudu země 79 a, pokud kvưli starým lidem zvítězí levice, osud to bude velmi soumračný. $V$ textu je referováno ke třem odměnám: budoucnosti země, návštěvě „zdarma“ a odkazu na „nejlepší animální anální porno se členkou italský parlamentní strany, Rocco Siffredim a úhořem“, tentokrát „úplně zadarmo“. Třetí jmenovaná je okamžitá odměna pro mladé, druhá je rychlou odměnou pro starší. První odměna - slibná budoucnost země - je explicitně spojena s mladými, slabě a implicitně i se staršími, protože „vnoučata [jsou pro ně] to nejdůležitější na světě“ a zřejmě ji vnoučatům nebudou chtít komplikovat (a kdyby přesto ano - „když nezafunguje zdravej rozum, použijte nátlak"). Zajímavé na druhé a třetí odměně jsou jejich rychlá a snadná („zdarma“) dostupnost. To by mohlo vyjadřovat komodifikovanost diskurzu Issové a Mádla, nebo - s odkazem na žánr - parodii vše prostupující obchodovatelnosti v pozdní modernitě. Komodifikace je podle Fairclougha další z významných tendencí pozdně moderního diskurzu. ${ }^{80}$

Nerozhodnutelnost, respektive nemožnost odhalení ,pravého významu' a chaotičnost vznikající z nezastavitelných znakových řetězců je mo-

78 Fairclough (1993, s. 201-207).

79 Srovnej Linek \& Lyons (2013).

8o Fairclough (1993, s. 207-215). 
torem imaginativní zběsilosti postmodernismu a je současně jeho obrovskou výsadou i ztrátou. Přestože napětí pozdní modernity ilustruje celkem výstižně, při aplikaci na ,každodenní, ,reálný,, ,praktický život může velmi jednoduše působit jako irelevantní i necitlivé fantazírování. Důležitější pak není, jestli a jak otevírá nové prostory pro myšlení, ale to, jak znepřehledňuje ty stávající. Postmoderní aktualizace politického diskurzu (předvolební klipy ve stylu filmových trailerů či i používání ironie, slovní nebo obrazové v metaforických stylizacích klipů) jsou asi častěji nefunkční, protože je jen těžko uvěřitelné, že by politik mohl vystupovat jako nespolehlivý vypravěčc ${ }^{81}$, který vědomě prezentuje svůj fragmentární pohled na svět a sobě nepohodlné zapomíná či zamlčuje. ${ }^{82}$

Zdá se mi, že Issová a Mádl velmi podcenili přenositelnost postmoderních principů z oblasti fikce (literatura, filmy atd.) do oblasti politiky, v níž je potřeba rozlišovat pravdivé a lživé či nekompletní informace stále zásadní. Jejich prohlášení o starších lidech, která mohla být i přeháněním a dílčí parodií politiky, tak zněla jako vážně pronášené názory a takto byla urážlivá. Ačkoli herci v klipu mnohokrát ukázali vlastní nespolehlivost a mohli tak varovat, aby lidé nebrali všechna jejich vyjádření doslova, byl předpoklad, že diváci v tomto zmatku rozpoznají apel na potřebnost diskuze, celkem nerealistický. Navíc postmoderně si hrát a současně trvat na souvislosti mezi logikou jednání podporovanou komunismem s konkrétními politickými stranami i naivně věřit rétorice o rozpočtové zodpovědnosti bylo opět neprozřetelné. ${ }^{83}$ Že bylo úmyslem diskuzi povzbudit, ne zablokovat, na důsledcích klipu - způsobech jeho čtení a vyostření vztahu starších a mladších, levicově a pravicově smýšlejících, na vesnici či ve městě žijících - mnoho nezmění. Klip je tak určitým mementem, jak do politického diskurzu nevstupovat. Nespolehlivý vypravěč se tu totiž přesmyká v populistu.

81 Srovnej Kubíček (2007).

82 Srovnej s mechanismem univerzalizace, např. Thompson (2010, s. 61).

83 Jsem si přitom vědoma, že takové soudy jsou pro mne snadné, protože jsou zpětné, tedy čerpají ze znalosti zpo̊sobů, jak byla ona politika rozpočtové zodpovědnosti uskutečněna. 


\section{Literatura}

Andersen, N. (2003): Discursive Analytical Strategies: Understanding Foucault, Koselleck, Laclau, Luhmann. Policy Press, Bristol. Angermuller, J., Maingueneau, D. \& Wodak, R. (2014): The Discourse Studies Reader: Main currents in theory and analysis. John Benjamins Publishing Company, Amsterdam.

[Rubeš, J. \& Stýblo, Č.] (2010): „Zabij bábu!“ In Youtube [online]. 27. 4. 2010 [cit. 8. 11. 2018]. Dostupné z: https://www.youtube.com/ watch?v=B_Q59QE9M98.

Berger, P. L. \& Luckmann, T. (1999): Sociální konstrukce reality: pojednání o sociologii vědění. Centrum pro studium demokracie a kultury, Brno.

Bourdieu, P. (1991): Language and Symbolic Power. Harvard University Press, Cambridge.

Bourdieu, P. (1998): Teorie jednání. Karolinum, Praha.

Creswell, J. W. (2007): Qualitative Inquiry and Research Design:

Choosing Among Five Approaches. Sage, Thousand Oaks, London, New Delhi.

Culler, J. D. (1981): The Pursuit of Signs: Semiotics, Literature,

Deconstruction. Cornell University Press, Ithaca, N.Y.

Cvrček, V. \& Vondřička, P. (2013): KWords. FF UK, Praha.

[cit. 18. 11. 2018]. Dostupné z: http://kwords.korpus.cz.

Člověk v tísni (2010): Jeden svět na školách. Studentské volby 2010

[online] [cit. 18. 11. 2018]. Dostupné z: https://www.jsns.cz/ data/jsns/files/pdf/prirucka_-_studentske_volby.pdf.

Docker, J. (1994): Postmodernism and Popular Culture: A Cultural History. Cambridge University Press, Cambridge.

Drtinová, D. (2018): „Čekáme velké vůdce, kteří za nás všechno vyřeší, ř́ká herečka Issová." In DVTV [online]. 18. 11. 2018 [cit. 20. 11. 2018]. Dostupné z: https://video.aktualne.cz/dvtv/ cekame-velke-vudce-kteri-za-nas-vsechno-vyresi-rika-herecka/ r 594b826aeaa311e8a470ac1f6b220ee8/.

Eco, U. (2004): Meze interpretace. Karolinum, Praha.

Ezzy, D. (2002): Qualitative Analysis: Practice and Innovation. Routledge, London. 
Fairclough, N. (1993): Discourse and Social Change. Polity Press, London.

Fairclough, N. (1995a): Media discourse. Hodder Arnold, London, New York.

Fairclough, N. (1995b): Critical discourse analysis: the critical study of language. Longman, Harlow.

Fairclough, N. (2001): Language and power. Longman, Edinburgh.

Fairclough, N. (2003): Analysing discourse: textual analysis for social research. Routledge, London, New York.

Featherstone, M. (2007): Consumer Culture and Postmodernism. Sage, Los Angeles, London, New Delhi, Singapore.

Fowler, R. (1991): Language in the News: Discourse and Ideology in the Press. Routledge, London, New York.

Gee, J. P. (2005): An Introduction To Discourse Analysis: Theory And Method. Routledge, New York.

Gee, J. P. (2010): How to do Discourse Analysis: A Toolkit. Taylor \& Francis, New York, London.

Giddens, A. (2003): Důsledky modernity. Sociologické nakladatelství, Praha.

Goatly, A. (2007): Washing the Brain: Metaphor and Hidden Ideology. John Benjamins Publishing Company, Amsterdam, Philadelphia.

Hejdová, K. (2016): „Jiř̌́ Mádl: Míření na nejnižší pudy nemám rád. Víru nelze nikomu vecpat." In Forum24 [online]. 4. 6. 2016 [cit. 18. 11. 2018]. Dostupné z: http://forum24.cz/jiri-madlmireni-na-nejnizsi-pudy-nemam-rad-viru-nelze-nikomu-vecpat/.

Held, D. (1990): Introduction to Critical Theory: Horkheimer to Habermas. Polity Press, Cambridge.

Hřídel, J. (2010): „Přemluv bábu je nadsázka, říká Issová. Je to nevkusné, odpovídá Pehe." In ČT24 [online]. 27. 4. 2010 [cit. 18. 11. 2018]. Dostupné z: https://ct24.ceskatelevize.cz/ domaci/133998o-premluv-babu-je-nadsazka-rika-issova-jenevkusne-odpovida-pehe.

Hammersley, M. (2000): Taking Sides in Social Research: Essays on Partisanship and Bias. Routledge, London, New York. 
Herzog, B. (2016): „Discourse analysis as immanent critique:

Possibilities and limits of normative critique in empirical discourse studies." Discourse and Society 27 (3): 278-292.

Chen, K.-H. \& Morley, D., eds. (2006): Stuart Hall: Critical Dialogues in Cultural Studies. Taylor \& Francis, London, New York.

Chouliaraki, L. \& Fairclough, N. (1999): Discourse in Late Modernity: Rethinking Critical Discourse Analysis. Edinburgh University Press, Edinburgh.

Idnes.cz. (2010): „Přemluv bábu a dědu, at’ nevolí levici, apelují Mádl a Issová v klipu.“ In Idnes [online]. 22. 4. 2010. [cit. 18. 11. 2018]. Dostupné z: https://zpravy.idnes.cz/premluv-babu-a-deduat-nevoli-levici-apeluji-madl-a-issova-v-klipu-php-/domaci.

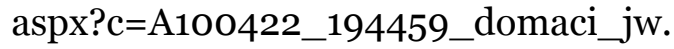

Ingarden, R. (1967): O poznávání literárního díla. Československý spisovatel, Praha.

Issová, M., Mádl, J. \& Zelenka, P. (2010): „Přemluv bábu.“ In Youtube [online]. 22. 4. 2010 [cit. 18. 11. 2018]. Dostupné z: https://www. youtube.com/watch?v=MLfFhdcXJhA.

Jorgensen, M. \& Phillips, L. (2002): Discourse Analysis as Theory and Method. Sage, London, Thousand Oaks, New Delhi.

Karlík, P. (2003): „Věta.“ In Příruční mluvnice češtiny, eds. P. Karlík, M. Nekula \& Z. Rusínová, Nakladatelství Lidové noviny, Praha, s. $369-567$.

Keller, J. (2017): Evropské rozpory ve světle migrace. Slon, Praha. Kirkosová, K., Urbániková, M. \& Volek, J. (2012): „Transformations of the EU Agenda in the Pre-Election Czech Press: A Comparative Content and Discourse Analysis." In XXII World Congress of Political Science, Madrid.

Krčmová, M. \& Chloupek, J. (2017): „Národní jazyk.“ In CzechEncy Nový encyklopedický slovník češtiny, eds. P. Karlík, M. Nekula \& J. Pleskalová [online] [cit. 18. 11. 2018]. Dostupné z: https:// www.czechency.org/slovnik/NÁRODNÍ\%20JAZYK.

Kress, G. (2010): Multimodality: A Social Semiotic Approach to Contemporary Communication. Taylor \& Francis, London, New York. 
Kress, G. R. \& van Leeuwen, T. (2006): Reading Images: The

Grammar Of Visual Design. Routledge, London, New York.

Krzyżanowski, M. \& Forchtner, B. (2016): „Theories and concepts in critical discourse studies: Facing challenges, moving beyond foundations." Discourse and Society 27 (3): 253-261. DOI: https://doi.org/10.1177/0957926516630900.

Kubíček, T. (2007): Vypravěč. Kategorie narativní analýzy. Host, Brno.

Lakoff, G. \& Johnson, M. L. (2002): Metafory, kterými žijeme. Host, Brno.

Linek, L. \& Lyons, P. (2013): Dočasná stabilita?: volební podpora politických stran v České republice v letech 1990-2010. Sociologické nakladatelství (SLON), Sociologický ústav AV ČR, Praha.

Lingea (2012): Slouník českých synonym a antonym [online]. Lingea, Brno, (C) 2012 [cit. 8. 11. 2018]. Dostupné z: https://www. nechybujte.cz/slovnik-ceskych-synonym/p\%C5\%99emluv.

Lyotard, J.-F. (1993): O postmodernismu. Filosofia, Praha.

McRobbie, A. (2003): Postmodernism and Popular Culture. Taylor \& Francis, London, New York.

Mills, S. (1997): Discourse. Routledge, London, New York.

Nekula, M. (2003a): „Aktuální členění.“ In Př́ruční mluvnice češtiny, eds. P. Karlík, M. Nekula \& Z. Rusínová, Nakladatelství Lidové noviny, Praha, s. 633-644.

Nekula, M. (2003b): „Koherence textu.“ In Př́ruční mluvnice češtiny, eds. P. Karlík, M. Nekula \& Z. Rusínová, Nakladatelství Lidové noviny, Praha, s. 681-698.

Perknerová, K. (2010): „Kalousek pro Deník: ČSSD i ODS nás vedou do Řecka." In Deník [online]. 11. 5. 2010 [cit. 18. 11. 2018]. Dostupné z: https://www.denik.cz/z_domova/kalousek-cssd-i-ods-nasvedou-do-recka20100510.html.

Reisigl, M. \& Wodak, R. (2001): Discourse and Discrimination: Rhetorics of Racism and Antisemitism. Routledge, London, New York. 
Richardson, J. E. (2007): Analysing newspapers: an approach from critical discourse analysis. Palgrave Macmillan, Hampshire, New York.

Ritchie, J. \& Lewis, J. (2003): Qualitative Research Practice: A Guide for Social Science Students and Researchers. Sage, London.

Schneiderová, S. (2016): Analýza diskurzu a mediální text. Praha, Karolinum.

Strnadová, T. (2010): „Studenti potopili ČSSD, jejich volby vyhrála TOP o9. Uspěli i neonacisté." In Idnes [online]. 14. 5. 2010 [cit. 18.

11. 2018]. Dostupné z: https://zpravy.idnes.cz/studenti-potopilicssd-jejich-volby-vyhrala-top-o9-uspeli-i-neonaciste-1ea-/ domaci.aspx?c=A100513_215618_studium_jan.

Švihlíková, I. \& Tsivos, K. (2017): Řecká tragédie. Novela bohemica, Praha.

Talbot, M. (2007): Media Discourse: Representation and Interaction. Edinburgh University Press, Edinburgh.

Thompson, J. B. (1990): Ideology and Modern Culture: Critical Social Theory in the Era of Mass Communication. Stanford University Press, Cambridge.

ÚJČ AV ČR. Internetová jazyková příručka [online]. Ústav pro jazyk český AV ČR, Praha, (C) 2008-2018 [cit. 8. 11. 2018]. Dostupné z: http://prirucka.ujc.cas.cz/.

van Dijk, T. A. (2001): „Multidisciplinary CDA: a plea for diversity.“ In Methods of Critical Discourse Analysis, eds. R. Wodak \& M. Meyer, Sage, London, s. 95-120.

Van Leeuwen, T. (2008): Discourse and Practice: New Tools for Critical Discourse Analysis. Oxford University Press, Oxford, New York.

Vilček, I. (2010): „Oklamte Čecha, vyzývá slovenské důchodce parodie na klip Mádla a Issové." In Novinky [online]. 3. 5. 2010 [cit. 18. 11. 2018]. Dostupné z: https://www.novinky.cz/zahranicni/ evropa/199193-oklamte-cecha-vyzyva-slovenske-duchodceparodie-na-klip-madla-a-issove.html.

Vokál, V. (2016): „Klip Přemluv bábu uspěl. Mádl toho nelituje.“ In Idnes [online]. 16. 6. 2016 [cit. 20. 11. 2018]. Dostupné z: https:// 
tv.idnes.cz/klip-premluv-babu-uspel-madl-toho-nelituje-fjh-/ domaci.aspx?idvideo=V160616_165317_kultura_sha.

Wagner, P. (1994): A Sociology of Modernity: Liberty and Discipline. Routledge, London, New York.

Wengraf, T. (2001): Qualitative Research Interviewing: Biographic Narrative and Semi-Structured Methods. Sage, London, Thousand Oaks, New Delhi.

Wodak, R. (2001): „The discourse-historical approach.“ In Methods of Critical Discourse Analysis, eds. R. Wodak \& M. Meyer, Sage, London, s. 63-94.

Wodak, R. (2008): „Introduction: Discourse Studies - Important Concepts and Terms." In Qualitative discourse analysis in the social sciences, eds. R. Wodak \& M. Krzyzanowski, Palgrave Macmillan, New York, s. 1-29.

Wodak, R. \& Meyer, M. (2009): „Critical Discourse Analysis: History, Agenda, Theory, and Methodology." In Methods for Critical Discourse Analysis, eds. R. Wodak \& M. Meyer, Sage, London, S. $1-33$.

Wodak, R., de Cillia, R., Reisigl, M. \& Liebhart, K. (2009): Discursive Construction of National Identity. Edinburgh University Press, Edinburgh.

\section{Abstract}

Convince Your Grandma, Amuse Yourself: Postmodern Aesthetics in Civic Political Discourse

In this paper, I analyze the viral video Přemluv bábu (Convince your grandma, 2010), which had the ambition to intervene in the elections to the Chamber of Deputies of the Czech Republic in 2010. I view the clip from a Critical Discourse Analysis (CDA) position and work primarily with Norman Fairclough's concepts and analytical tools. I argue that the clip benefits from both the flexibility and evasiveness of postmodern discourse, which may have weakened and confused its message rather than making it more engaging. I demonstrate this insight on many examples from various levels of text analysis and try to understand the identified ambivalence with respect to the intertextual, interdiscursive, situational and socio-political context. 
Key words: critical discourse analysis, political discourse, media discourse, postmodernism, Convince your grandma

Kirkosová, K. (2018): „Přemluv bábu, pobav sebe: postmoderní estetika v občanském politickém diskurzu." Filosofie dnes 10(2): 175-207. Dostupné z www.filosofiednes.ff.uhk.cz 